ORIGINAL ARTICLE

\title{
Modelling to obtain expanded cowpea products in a twin screw extruder
}

\section{Modelagem para obtenção de produtos expandidos de feijão- caupi em extrusora de dupla rosca}

\author{
Jorge Minoru Hashimoto $^{1 *}$ (D), Marcio Schmiele ${ }^{2}$ (D) Elizabeth Harumi Nabeshima $^{3}$ (i) \\ ${ }^{1}$ Empresa Brasileira de Pesquisa Agropecuária Meio-Norte (EMBRAPA Meio-Norte), Teresina/PI - Brasil. \\ ${ }^{2}$ Universidade Federal dos Vales do Jequitinhonha e Mucuri, Instituto de Ciência e Tecnologia - Engenharia de \\ Alimentos, Diamantina/MG - Brasil \\ ${ }^{3}$ Instituto de Tecnologia de Alimentos (ITAL), Campinas/SP - Brasil.
}

*Corresponding Author: Jorge Minoru Hashimoto, Empresa Brasileira de Pesquisa Agropecuária Meio-Norte (EMBRAPA Meio-Norte), Av. Duque de Caxias, 5650, Bairro Buenos Aires, CEP: 64008-780, Teresina/PI - Brasil, e-mail: jorge.hashimoto@embrapa.br

Cite as: Hashimoto, J. M., Schmiele, M., \& Nabeshima, E. H. (2021). Modelling to obtain expanded cowpea products in a twin screw extruder. Brazilian Journal of Food Technology, 24, e2020111.

https://doi.org/10.1590/1981-6723.11120

\begin{abstract}
Cowpea grains are nutritious and beneficial to health, contain about $25 \%$ of proteins, in addition to carbohydrates, vitamins, minerals, and bioactive compounds. Soaking the beans followed by cooking requires time availability that is incompatible with the current lifestyle. Consumers have opted for read-to-eat, attractive, healthy, nutritious and convenient foods, thus, transforming cowpeas into crispy expanded product is promising. This research aimed to evaluate the effect of the extrusion conditions, moisture, and temperature, on the physical characteristics of the extrudates developed from cowpea cotyledons flour (CCF): from cultivar BRS Guariba (Sorriso, MT, Brazil). The CCF was processed using twin-screw thermoplastic extruder ZSK 30 (Werner \& Pfleiderer Co.) varying the moisture (16.2\% to $21.8 \%$ ) and temperature $\left(124\right.$ to $\left.166^{\circ} \mathrm{C}\right)$ using Central Composite Rotatable design $2^{2}$. The expansion index values ranged from 3.01 to 3.98 , the regression model was not predictive, with the determination coefficient $\left(r^{2}\right)$ equal to 0.67 . The independent variables studied presented significant effects, being water solubility index affected by the CCF moisture, compression force ( 15.63 to $47.72 \mathrm{~N}$ ) affected by the extruder temperature, the water solubility index ( $28.34 \%$ to $43.67 \%)$ by moisture, while the specific volume $\left(2.41\right.$ to $\left.4.58 \mathrm{~mL} \mathrm{~g}^{-1}\right)$ and the water absorption index (5.34 to $6.54 \mathrm{~g} \mathrm{~g}^{-1}$ ) were affected for both variables. By simulation, the maximum value of 1 was obtained through the global desirability test in the combination of an extrusion temperature of $124.21{ }^{\circ} \mathrm{C}$ and conditioning moisture of CCF of $16.28 \%$. This condition favors obtaining extrudates with greater values for a specific volume and water absorption index, and lower values for compression force and water solubility index.
\end{abstract}

Keywords: Vigna unguiculata; Expansion; Flour; Cotyledons; Dehulled; Extruded.

\section{Resumo}

Os grãos de feijão-caupi são nutritivos e benéficos à saúde, contêm cerca de $25 \%$ de proteínas, além de carboidratos, vitaminas, minerais e compostos bioativos. Colocar o feijão de molho seguido do cozimento exige uma disponibilidade de tempo incompatível com o estilo de vida atual. Os consumidores têm optado por alimentos 
prontos para o consumo, atrativos, saudáveis, nutritivos e convenientes, portanto, transformar o feijão-caupi em produto expandido crocante é promissor. O objetivo deste trabalho foi avaliar o efeito do teor de umidade e da temperatura de extrusão sobre as características físicas dos produtos expandidos desenvolvidos com farinha de cotilédones de feijão-caupi (FCFC) da cultivar BRS Guariba (Sorriso, MT, Brasil). A FCFC foi processada utilizando extrusor termoplástico de dupla rosca ZSK 30 (Werner \& Pfleiderer Co.), variando os teores de umidade de condicionamento $\left(16,2 \%\right.$ a 21,8\%) e temperaturas de extrusão (124 a $166{ }^{\circ} \mathrm{C}$ ) utilizando um delineamento experimental composto central rotacional $2^{2}$. Os valores do índice de expansão variaram de 3,01 a 3,98 e o modelo de regressão não foi preditivo, com o coeficiente de determinação $\left(r^{2}\right)$ igual a 0,67 . As variáveis de processo estudadas afetaram significativamente as propriedades físicas dos extrusados. A força de compressão $(15,63$ a 47,72 N) foi afetada pela temperatura de extrusão, o índice de solubilidade em água (28,34\% a 43,67\%) pela umidade, enquanto o volume específico $\left(2,41\right.$ a 4,58 $\left.\mathrm{mL} \mathrm{g}^{-1}\right)$ e o índice de absorção de água (5,34 a 6,54 $\left.\mathrm{g} \mathrm{g}^{-1}\right)$ foram afetados pelas duas variáveis. Por simulação, obteve-se, por meio do teste de desejabilidade global, valor máximo igual a 1 , na combinação de temperatura de extrusão de $124,21^{\circ} \mathrm{C}$ e umidade de condicionamento da FCFC de $16,28 \%$, condição que favoreceu a obtenção de extrusados com maiores valores para volume específico e índice de absorção de água, e menores valores para força de compressão e índice de solubilidade de água.

Palavras-chave: Vigna unguiculata; Expansão; Farinha; Cotilédones; Descorticado; Extrusado.

\section{Introduction}

In 2018, Brazil produced about 738 thousand tons of cowpea [Vigna unguiculata (L.) Walp.].This pulse species is the second most produced in Brazil and represents $25 \%$ of the total produced ( 3 million tons) of beans (Empresa Brasileira de Pesquisa Agropecuária, 2020), which places the country in the $3^{\text {rd }}$ position in quantity of world production, behind Nigeria (2.6 million tons) and Niger (2.4 million tons) and ahead of Burkina Faso (631 thousand tons) (Food and Agriculture Organization of the United Nations, 2020). For the Northeast region of Brazil, $87 \%$ of pulses production is represented by cowpea, demonstrating its importance and predominance, due to the attributes of the plant, such as broad adaptability, associate in symbiosis with nitrogen-fixing bacteria, rusticity, tolerance to high temperature conditions, and soil water deficit, being a low-cost food for the population and is sustainable (Food and Agriculture Organization of the United Nations, 2015).

Cowpea grains are a nutritious source of protein, energy, vitamins, minerals, very low in fat and sodium. The high content of soluble dietary fiber can help to lower blood cholesterol, the main risk factor in cardiovascular disease and stroke. Nutrients, bioactive compounds, and small amounts of antinutrients remaining help in the cooked grains in the prevention and/or control of chronic diseases, such as heart disease, obesity, strokes, cancers, and respiratory diseases (Rondini et al., 2013), and enhancing other aspects related to health (Food and Agriculture Organizations of the United Nations, 2015).

The composition of cowpea grains on a dry basis (d.b.) has $26.7 \%$ of protein, $68.3 \%$ of carbohydrates, $3.6 \%$ of ash, $1.4 \%$ of lipids, $10.6 \%$ of total dietary fiber, including vitamins A, E, K, and B complex (United States Department of Agriculture, 2017). Although they are limiting in sulfur amino acids, the profile of these components meets the requirements of preschoolers and adults (Institute of Medicine of the National Academies, 2005). Despite the nutritional and health benefits, annual per capita consumption of beans has decreased from 23, 20,16, and $17 \mathrm{~kg}$ in the 1960s, 70, 80, and 90, respectively (Ferreira \& Wander, 2017), maintaining at $17 \mathrm{~kg}$ with oscillations (Wander \& Chaves, 2011; Brasil, 2018).

Urbanization and the insertion of women into the labor market have led to changes in the food habits of the population and have given rise to new demands regarding quality, presentation, ease, and less time of preparation (Ferreira et al., 2002). The transformation of nutritious and healthy grains into ready-to-eat food is a worldwide trend in food consumption (Instituto de Tecnologia de Alimentos, 2015). Expanded extrudates have been one of the most successful types of convenience foods, produced through versatile and efficient 
technology. However, consumers have realized that those produced solely based on cereals or starch are highly caloric and nutrient-poor (Korkerd et al., 2016).

Traditionally consumed cooked cowpea beans are nutritious and beneficial to health, and the long cooking time can be replaced by thermoplastic extrusion, which in addition to thermal processing, allows you to obtain a dehydrated product with low water activity, expanded, crunchy, and can be ready-to-eat. To improve the degree of expansion, it is recommended to dehull the grain, as they have a high content of fibers, which limit and hinder expansion at decompression of the cooked material at the exit of the die (Aguilera et al., 1982). In addition to the expansion benefit, the dehulling of grain is a practice that maximizes the nutritional value of the raw material (Wood \& Malcolmson, 2011), because it removes the tegument that has little nutritional value in terms of proteins and energy, and contains antinutrients.

The first works in a single screw extruder using cowpea cotyledons flour (CCF) were carried out by Phillips et al. (1984) and Kennedy et al. (1986), with mechanical dehulling done in dry grains by abrasion and friction, according to Phillips (1982). In these complementary studies, adjustments were made in the moisture content of the CCF to $20 \%, 30 \%$, or $40 \%$, followed by storage in hermetic packaging for about 20 hours for homogeneous hydration of the CCF particles, before extruding at 150,175 , or $200^{\circ} \mathrm{C}$. There are no reports of other research using only the dehulled flour or CCF. Further research on cowpea extrusion was carried out with whole cowpea flour (WCF) (Lira Filho, 2002; Marques, 2013; Batista et al., 2010; Strauta \& Muizniece-Brasava, 2016; Jakkanwar et al., 2018). Thus, the objective of this research was to evaluate the effect of the moisture and temperature on the physical characteristics of the extrudates developed with cowpea cotyledons flour.

\section{Material and methods}

\subsection{Cowpea Cotyledons Flour (CCF)}

Grains of cowpea BRS Guariba cultivar produced in Sorriso, Mato Grosso state, Brazil, were dehulled (Comercial MaqLand Ltda., Model DSF 2000, Londrina, PR, Brazil). The cotyledons were crushed in a knife mill (Máquinas Renard Indústria e Comércio Ltda., model MFC-180-75- 01 n 5753, São Paulo, SP, Brazil), with a $3 \mathrm{~mm}$ sieve coupled to the outlet and transformed into CCF in the roller mill (Brabender OHG, Quadrumat Senior model, Duisburg, North Rhine-Westphalia, Germany).

\subsection{Raw CCF chemical analysis}

The chemical composition of the raw CCF was determined according to the methods of the Association of Official Analytical Chemists (2012). The carbohydrate content was calculated by difference.

\subsection{Extrusion process}

CCF was processed in the co-rotating twin-screw extruder (Werner \& Pfleiderer Co., model ZSK 30, Ramsey, New Jersey, USA), screws $1030 \mathrm{~mm}$ length and $30 \mathrm{~mm}$ in diameter (L/D = 35), and with the following temperature settings: $1^{\text {st }}$ zone at $75^{\circ} \mathrm{C}, 2^{\text {nd }}$ zone at $100{ }^{\circ} \mathrm{C}, 3^{\text {rd }}$ zone always $10^{\circ} \mathrm{C}$ below the setting of the $4^{\text {th }}$ zone. The temperature of this zone and the moisture content of the CCF were adjusted according to the experimental design for three levels (Box \& Behnken, 1960), as shown in Table 1.

Two-hole matrix $2.8 \mathrm{~mm}$ in diameter, feed rate $13 \mathrm{~kg} \mathrm{~h}^{-1}$, rotation speed of the screws of $260 \mathrm{rpm}$, and a rotary knife at the die exit at $26 \mathrm{rpm}$ were used to cut the extrudates. The extrudates were collected 5 minutes after reaching the temperatures programmed in the respective zones and the stability of the equipment to the torque. The samples were then transferred to a rotary drum for drying (Inbramaq, model 2068, Ribeirão Preto, São Paulo, Brazil), adjusted to $95{ }^{\circ} \mathrm{C}$ for 1 minute, followed by drying in a forced air circulation oven at 
$80 \pm 0.2{ }^{\circ} \mathrm{C}$ (Tecnal, model TE-394/2, Piracicaba, São Paulo, Brazil) until reaching moisture between 6\% and $8 \%$. Part of the extrudates was ground in a blender (OXY, model OBL 10/2, Santana de Parnaíba, São Paulo, Brazil) at 35,000 rpm for $3 \mathrm{~min}$ and sieved in $0.5 \mathrm{~mm}$ mesh for determination of absorption and solubility in water.

\subsection{Analysis of extrudates}

\subsubsection{Expansion index (EI)}

The EI was determined by measuring the extrudate diameter with a caliper (Mitutoyo Inc., model 530312B10, Kawasaki, Takatsu-ku, Japan) and expressed as a ratio of extrudate diameter (DE) to the diameter of the orifice of the matrix (DO) (Hashimoto \& Grossmann, 2003). The measurement was performed in 6 segments of extrudates, randomly collected from each treatment to determine the mean value.

\subsubsection{Specific volume (SV)}

The SV was determined by the water displacement method (Hashimoto \& Grossmann, 2003) and expressed in $\mathrm{mL} \mathrm{g}^{-1}$. Randomly, 10 extruded segments of each treatment were collected and the individual weight of each segment was determined, followed by waterproofing with a thin layer of paraffin and subsequently immersed in water, and the respective displaced water volumes were quantified.

Table 1. Levels expressed in coded and real values of experimental conditions of experimental design $2^{2}$ of the cowpea cotyledon flour (CCF) extrusion process and averages of the values of the physical characteristics of the dependent variables.

\begin{tabular}{|c|c|c|c|c|c|c|c|c|c|}
\hline \multirow[b]{2}{*}{ Trial } & \multicolumn{2}{|c|}{ Encoded values } & \multicolumn{2}{|c|}{ Real values } & \multicolumn{5}{|c|}{ Dependents variables $^{2}$} \\
\hline & $\mathbf{x}_{1}$ & $\mathbf{x}_{2}$ & $\begin{array}{c}\text { Temperature }^{1} \\
4^{\text {th }} \text { zone }\left({ }^{\circ} \mathrm{C}\right) \\
\end{array}$ & $\begin{array}{c}\text { Moisture } \\
(\%)\end{array}$ & EI & $\begin{array}{c}\mathrm{SV} \\
\left(\mathrm{mL} \mathrm{g}^{-1}\right)\end{array}$ & $\begin{array}{l}\mathrm{CF} \\
(\mathrm{N})\end{array}$ & $\begin{array}{r}\text { WAI } \\
\left(\mathrm{g} \mathrm{g}^{-1}\right)\end{array}$ & $\begin{array}{l}\text { WSI } \\
(\%)\end{array}$ \\
\hline 1 & -1 & -1 & 130 & 17 & $3.60 \pm 0.17 b$ & $3.95 \pm 0.59 b$ & $26.15 \pm 2.69 \mathrm{c}$ & $6.32 \pm 0.09 \mathrm{a}$ & $29.95 \pm 0.62 \mathrm{~d}$ \\
\hline 2 & 1 & -1 & 160 & 17 & $3.03 \pm 0.16 \mathrm{~d}$ & $2.76 \pm 0.37 \mathrm{c}$ & $47.72 \pm 5.54 \mathrm{a}$ & $6.06 \pm 0.17 \mathrm{a}$ & $30.12 \pm 1.21 \mathrm{~d}$ \\
\hline 3 & -1 & 1 & 130 & 21 & $3.68 \pm 0.08 \mathrm{~b}$ & $3.15 \pm 0.50 \mathrm{~b}$ & $19.01 \pm 2.50 \mathrm{e}$ & $5.51 \pm 0.18 \mathrm{~b}$ & $42.82 \pm 0.37 \mathrm{a}$ \\
\hline 4 & 1 & 1 & 160 & 21 & $3.68 \pm 0.08 \mathrm{~b}$ & $4.58 \pm 1.07 \mathrm{a}$ & $18.98 \pm 1.12 \mathrm{e}$ & $5.82 \pm 0.13 b$ & $39.14 \pm 1.00 \mathrm{~b}$ \\
\hline 5 & $-\alpha$ & 0 & 123.8 & 19 & $3.54 \pm 0.26 \mathrm{~b}$ & $3.34 \pm 0.47 \mathrm{~b}$ & $27.80 \pm 4.62 \mathrm{c}$ & $6.54 \pm 0.06 \mathrm{a}$ & $28.34 \pm 0.17 \mathrm{~d}$ \\
\hline 6 & $\alpha$ & 0 & 166.2 & 19 & $3.19 \pm 0.17 \mathrm{~d}$ & $3.12 \pm 0.31 \mathrm{~b}$ & $15.63 \pm 2.24 \mathrm{e}$ & $5.72 \pm 0.23 b$ & $43.67 \pm 2.24 \mathrm{a}$ \\
\hline 7 & 0 & $-\alpha$ & 145 & 16.2 & $3.98 \pm 0.28 \mathrm{a}$ & $3.16 \pm 0.24 \mathrm{~b}$ & $23.21 \pm 2.64 \mathrm{~d}$ & $6.49 \pm 0.02 \mathrm{a}$ & $37.22 \pm 0.36 \mathrm{~b}$ \\
\hline 8 & 0 & $\alpha$ & 145 & 21.8 & $3.01 \pm 0.20 \mathrm{~d}$ & $3.91 \pm 0.63 \mathrm{~b}$ & $27.80 \pm 4.62 \mathrm{c}$ & $5.66 \pm 0.19 b$ & $38.54 \pm 1.60 \mathrm{~b}$ \\
\hline 9 & 0 & 0 & 145 & 19 & $3.36 \pm 0.20 \mathrm{c}$ & $2.86 \pm 0.62 \mathrm{c}$ & $30.95 \pm 3.05 b$ & $5.34 \pm 0.36 \mathrm{~b}$ & $33.78 \pm 1.86 \mathrm{c}$ \\
\hline 10 & 0 & 0 & 145 & 19 & $3.33 \pm 0.14 \mathrm{c}$ & $2.73 \pm 0.52 \mathrm{c}$ & $27.40 \pm 2.28 \mathrm{c}$ & $5.55 \pm 0.15 b$ & $37.21 \pm 1.44 b$ \\
\hline 11 & 0 & 0 & 145 & 19 & $3.46 \pm 0.18 \mathrm{~b}$ & $2.41 \pm 0.39 \mathrm{c}$ & $30.91 \pm 3.76 \mathrm{~b}$ & $5.68 \pm 0.26 \mathrm{~b}$ & $34.88 \pm 0.95 \mathrm{c}$ \\
\hline 12 & 0 & 0 & 145 & 19 & $3.38 \pm 0.09 \mathrm{c}$ & $2.56 \pm 0.46 \mathrm{c}$ & $33.89 \pm 4.17 \mathrm{~b}$ & $5.43 \pm 0.08 b$ & \\
\hline $\mathrm{Cru}$ & $\mathrm{CF}$ & - & & - & & - & - & $2.83 \pm 0.17$ & \\
\hline
\end{tabular}

\footnotetext{
${ }^{1}$ Temperature of the $3^{\text {rd }}$ zone was always $10{ }^{\circ} \mathrm{C}$ below this, the $1^{\text {st }}$ and $2^{\text {nd }}$ zones were 75 and $100{ }^{\circ} \mathrm{C}$, respectively. ${ }^{2} \mathrm{EI}=$ expansion index. $\mathrm{SV}$ $=$ specific volume $. \mathrm{CF}=$ compression force. $\mathrm{WAI}=$ water absorption index. WSI $=$ water solubility index. $\pm \alpha=$ axial points, for two independents variables $\alpha=\sqrt{2}=1.41$. Means followed by the same letter in the column do not differ statistically from each other by the ScottKnott clustering test $(p \leq 0.05)$.
}

\subsubsection{Compression force (CF)}

The CF was expressed in Newton $(\mathrm{N})$ and determined in the texture analyzer (TA-XT2, Stable Micro Systems, Haslemere-Surrey, UK) using a V-type Warner Bratzler (HDP / WBV) knife coupled to the load of $25 \mathrm{~kg}$ and 1 gram of sensitivity, pre-test speed, test and post-test $2.0 ; 1.0$ and $10 \mathrm{~mm} \mathrm{~s}^{-1}$, respectively. The determination was performed individually in each of the 8 extruded segments randomly collected from each treatment. 


\subsubsection{Water absorption (WAI) and water solubility index (WSI)}

The WAI and WSI were determined according to Anderson et al. (1969), in triplicate, in the CCF crude and extruded, with particle $<0.5 \mathrm{~mm}$. A $2.5 \mathrm{~g}$ sample (d.b.) was kept in $30 \mathrm{~mL}$ of distilled water at $25^{\circ} \mathrm{C}$ for $30 \mathrm{~min}$, under intermittent agitation in TECNAL ${ }^{\circledR}$ (Piracicaba, SP, Brazil) tubes with a capacity of $50 \mathrm{ml}$. The suspension was centrifuged (FANEM ${ }^{\circledR}$ centrifuge, Model 204NR, Guarulhos, SP, Brazil) at 2,200 g for $10 \mathrm{~min}$. The liquid supernatant from each tube was transferred to a Petri dish for drying in the oven (TECNAL ${ }^{\circledR}$ Brand oven, Model TE 394/2, Piracicaba, SP, Brazil), with air circulation and renewal at $105^{\circ} \mathrm{C}$ until constant weight. The WAI $\left(\mathrm{g} \mathrm{g}^{-1}\right)$ was obtained by dividing the weight of the gel by the result of the subtraction between the weight of the CCF (d.b., raw or extruded) and the respective dehydrated soluble residue. The ISA was obtained by dividing the weight of the soluble dehydrated solids by the weight of the CCF (d.b., raw or extruded), multiplied by 100 (Schmiele, 2009).

\subsection{Statistical analysis}

A Central Composite Rotatable design and the Response Surface Methodology were used, which allows extracting as much useful information as possible by performing a minimum of experiments (Khuri \& Cornell, 1990). For two independent variables, 4 axial points are included in the design, trials 5 to 8 (Table 1), equidistant from $\sqrt{ } 2=1.41$ units coded from the central point, allowing the obtainment of quadratic models (Barros Neto et al., 2010), and 3 repetitions of the central point, trials 10 to 12 (Table 1) to estimate the pure error. Through the regression analysis, it was possible to evaluate the combined effects of the parameters on the physical and physical-chemical characteristics of the extrudates. The dependent variables were: EI, SV, $\mathrm{CF}$, WAI, and WSI. Data were submitted to multiple regression analysis using the Statistica program (StatSoft, Version 10, OK, USA). The second order polynomial model was selected to predict the region of the optimal point of the responses, being expressed according to the general equation (Equation 1):

$$
y=\beta_{0}+\beta_{1} x_{1}+\beta_{2} x_{2}+\beta_{11} x_{1}^{2}+\beta_{22} x_{2}^{2}+\beta_{12} x_{1} x_{2}
$$

Where, $y$ represents the response variable, $\beta_{0}, \beta_{1}$, and $\beta_{2}$ are estimators of linear parameters, $\beta_{11} \beta_{22}$ are the quadratic terms, and $\beta_{12}$ the model interaction term. The independent variables $\mathrm{x}_{1}$ and $\mathrm{x}_{2}$ were the coding for temperature and moisture, respectively. The significant experimental models $(p \leq 0.05)$ were submitted to analysis of global desirability, in an equity condition, adopting values of "s" and " $\mathrm{t}$ " equal to 1 , to identify the process condition that favors the desirable characteristics: high values for SV and WAI, and low values for CF and WSI. Data were also submitted to analysis of variance and clustering test of Scott-Knott $(p \leq 0.05)$ using the software Sisvar 5.4 (Ferreira, 2008).

\section{Results and discussion}

\subsection{Composition of the raw material}

The crude CCF contained (d.b.): $23.98 \pm 0.28 \%$ of proteins; $1.89 \pm 0.10 \%$ of lipids; $4.22 \pm 0.03 \%$ ash and $69.92 \pm 0.16 \%$ carbohydrate. In a comparative study, it was demonstrated that BRS Guariba CCF presented higher protein contents than whole meal (Rios et al., 2018). Deshpande et al. (1982) reported an increase in protein, lipid, and ash content in cotyledon flour of 10 common bean cultivars after removal of the tegument, a predictable fact, considering that the tegument represents $6,9 \%$ to $9,8 \%$ of the grain weight. Aguilera et al. (1982) reported $7 \%$ to $13 \%$ of the hull, containing (d.b.): proteins (14.9\%), with higher values of ash (6.7\%), crude fiber (25.5\%), and dietary fiber (40.4\%). Considering that the fibers act as a bulky diluent, the removal of the integument favors the increase of the protein and lipids content in the CCF. 


\subsection{Expansion index of extrudates}

The EI is an index of the degree of expansion, being an important physical characteristic of the extrudate (Omohimi et al., 2014). This feature is related to the size, quantity, and distribution of the air cells within the extruded material. The EI value depends on the ability of the viscous material to form water vapor cells at the time of exit through the die when decompression occurs at atmospheric pressure, causing the instantaneous evaporation of the water from the viscous mass, forming the air cells, which remains structured due to a rapid and significant reduction in the water content that was contained in the viscous mass (Mesquita et al., 2013).

The EI values ranged from 3.01 to 3.98 (Table 1), the model that best represents the response behavior is presented in Equation 2. The highest mean value for EI was 3.98, obtained at $145{ }^{\circ} \mathrm{C}$ and $16.2 \%$ moisture (Figure 1), being significantly $(p \leq 0.05)$ higher than the other treatments (Table 1$)$.

$$
E I=3.38+0.03 x_{1}+0.01 x_{1}^{2}-0.24 x_{2}+0.07 x_{2}^{2}+0.14 x_{1} x_{2}
$$

The values obtained in this research were higher than those obtained by Phillips et al. (1984), who obtained an EI variation from 0.91 to 1.89 , also using CCF. The other researchers used single screw extruded and processing conditions similar to this research, however, extruded whole cowpea flour (WCF), which resulted in lower IE values, due to the tegument fibers: Lira Filho (2002) obtained EI values from 0.77 to 2.51, extruding at a temperature of 116 to $184{ }^{\circ} \mathrm{C}$, in moisture level of 18 to $28 \%$ and screw speed rotation of 106 to $174 \mathrm{rpm}$ and circular die with a diameter of $3 \mathrm{~mm}$; Marques (2013) obtained EI value of 2.46, extruding at temperature of $190{ }^{\circ} \mathrm{C}$, in moisture level of $18 \%$ and screw speed rotation of $200 \mathrm{rpm}$, or in moisture level of $28 \%$ and screws speed rotation of $100 \mathrm{rpm}$; Batista (2010) obtained EI value of 1.74 , extruding at $130{ }^{\circ} \mathrm{C}$, moisture level of $20 \%$ and rotation screw speed of $150 \mathrm{rpm}$; Jakkanwar et al. (2018) obtained EI values from 1.11 to 1.49 , at $180{ }^{\circ} \mathrm{C}, 16 \%$ moisture content and $200 \mathrm{rpm}$; Strauta \& Muizniece-Brasava (2016) obtained extrudates with lower diameters ( 8 to $9 \mathrm{~mm}$ ) than the observed in this research $(8.43$ to $11.14 \mathrm{~mm}$ ).

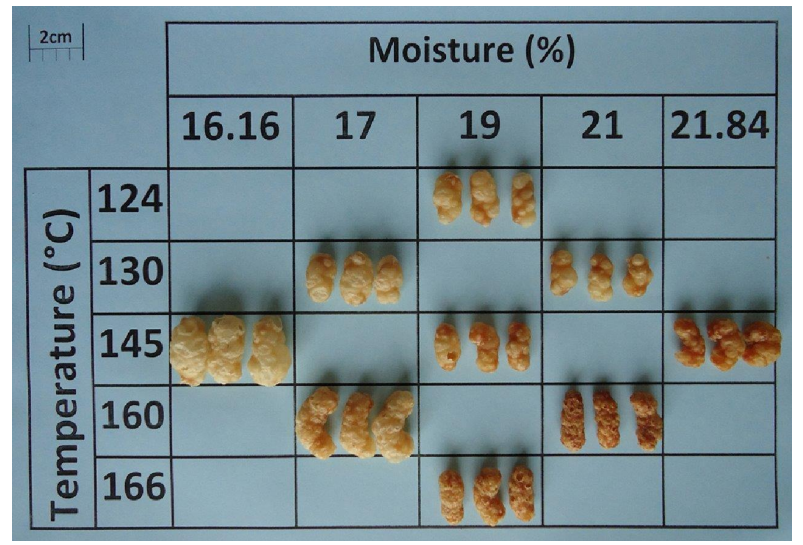

Figure 1. Expanded extrudates made from cotyledons cowpea flour (CCF)

Compared to traditional corn extrudates, EI has been reported close to 3 (Jozinovic et al., 2012) and 3.28 (Carvalho et al., 2010). Kaur et al. (2015) obtained a higher IE value (2.58) by reducing protein content in corn grits by adding $30 \%$ starch-rich banana flour. The increase in protein and fiber contents are factors that make it difficult to expand the extrudates (Anton et al., 2009; Korkerd et al., 2016), removal of tegument reduces fiber content, one of the reasons why CCF presented an EI value higher than those of the cited works that used WCF. The highest values for IE obtained by Jozinovic et al. (2012) extruding only corn grits were $\leq 3$, values lower than those observed in the present research, although the CCF contains about $25 \%$ (d.b.) of protein. The obtained regression model was not predictive $\left(r^{2}=0.67\right)$, and only the linear coefficient of moisture was significant (Table 2). 


\subsection{Specific volume of extrudates}

The SV represents the volume occupied by a given mass of structured extrudate, being the main performance index of an extruded product (Mesquita et al., 2013). The combination of high temperatures $\left(166{ }^{\circ} \mathrm{C}\right)$ and high moisture contents $(21.8 \%)$ favored the increase in SV value in the products, probably both conditions were propitious to make the cooked mass pressurized inside the extruder sufficient malleable, capable of expanding by forming several water vapor cells with depressurization upon exiting the die and the temperature was also sufficient to expel much of the moisture to render the starch and protein structure rigid, preventing collapse. Very high temperatures can cause water vapor bubbles to burst (Yuliani et al., 2006), as they make the walls too thin to withstand abrupt decompression. Probably low temperatures may not be enough to generate the pressure required for expansion and very low moisture may also be insufficient to adequately gelatinize the starch, or cause intense dextrinization due to shear, and if the moisture is too high, an amount of water will remain in the matrix, causing the collapse due to the structure not becoming stiff. Falcone \& Phillips (1988) demonstrated the negative effects of high temperature and moisture.

Table 2. Values of coefficients estimated by multiple linear regression for EI, SV, CF, WAI, and WSI of extrudates of CCF.

\begin{tabular}{cccccc}
\hline Coefficients & EI & SV & CF & WAI & WSI \\
\hline$\beta_{0}$ & $3.38^{*}$ & $2.64^{*}$ & $30.79^{*}$ & $5.50^{*}$ & $36.01^{*}$ \\
\hline$\beta_{1}$ & $0.03^{\text {ns }}$ & $0.26^{*}$ & $-6.64^{*}$ & $-0.28^{*}$ & $5.45^{*}$ \\
\hline$\beta_{11}$ & $0.01^{\mathrm{ns}}$ & $0.50^{*}$ & $-3.45^{\mathrm{ns}}$ & $0.27^{*}$ & $-0.36^{\mathrm{ns}}$ \\
\hline$\beta_{2}$ & $-0.24^{*}$ & $-0.01^{\mathrm{ns}}$ & $3.50^{\mathrm{ns}}$ & $-0.14^{\mathrm{ns}}$ & $-0.21^{\mathrm{ns}}$ \\
\hline$\beta_{22}$ & $0.07^{\mathrm{ns}}$ & $0.35^{*}$ & $-1.55^{\mathrm{ns}}$ & $0.24^{*}$ & $0.58^{\mathrm{ns}}$ \\
\hline$\beta_{12}$ & $0.14^{\mathrm{ns}}$ & $0.66^{*}$ & $-5.40^{\mathrm{ns}}$ & $0.14^{\mathrm{ns}}$ & $-0.96^{\mathrm{ns}}$ \\
\hline $\mathbf{r}^{\mathbf{2}}$ & $\mathbf{0 . 6 7}$ & $\mathbf{0 . 9 4}$ & $\mathbf{0 . 8 3}$ & $\mathbf{0 . 8 3}$ & $\mathbf{0 . 9 2}$ \\
\hline F value & $2.49^{\mathrm{ns}}$ & $9.23^{*}$ & $5.94^{*}$ & $5.98^{*}$ & $14.66^{*}$ \\
\hline $\mathrm{p}$ & $0.15^{\mathrm{ns}}$ & $0.0087^{*}$ & $0.0254^{*}$ & $0.0251^{*}$ & $0.0026^{*}$ \\
\hline Lack of fit & $0.0098^{*}$ & $0.44^{\mathrm{ns}}$ & $0.10^{\mathrm{ns}}$ & $0.15^{\mathrm{ns}}$ & $0.64^{\mathrm{ns}}$ \\
\hline
\end{tabular}

$\mathrm{EI}=$ expansion index. $\mathrm{SV}=$ specific volume. $\mathrm{CF}=$ compression force. WAI $=$ water absorption index. WSI $=$ water solubility index. * Significant $(p \leq 0.05) ;{ }^{\mathrm{ns}}=$ No significant.

As the values of the two independent variables decreased to near the center point values (0), a decrease in SV value gradually occurred. The continuation of the decrease in the values of these two independent variables below the values of the central point (0) caused an increase in the value of SV, but not in the same magnitude when the values of these independent variables were above the value of the central point $(0)$ (Figure 2a)

The value of SV ranged from 2.41 to $4.58 \mathrm{~mL} \mathrm{~g}^{-1}$ for all combinations, the highest value was obtained at $160{ }^{\circ} \mathrm{C}$ and $21 \%$ moisture, differing significantly from the other extrusion conditions (Table 1 ). The $r^{2}$ value was 0.94 and the regression model that explained this behavior was significant $(p=0.0087)$. Only the linear coefficient of moisture was not significant, this shows that temperature and moisture were important for the $\mathrm{SV}$, the interaction of these two variables was the one with the highest coefficient value $\left(\beta_{12}=0.66\right)$, all the coefficients presented positive values. The best model representing the behavior of the response surface is represented in Equation 3: 

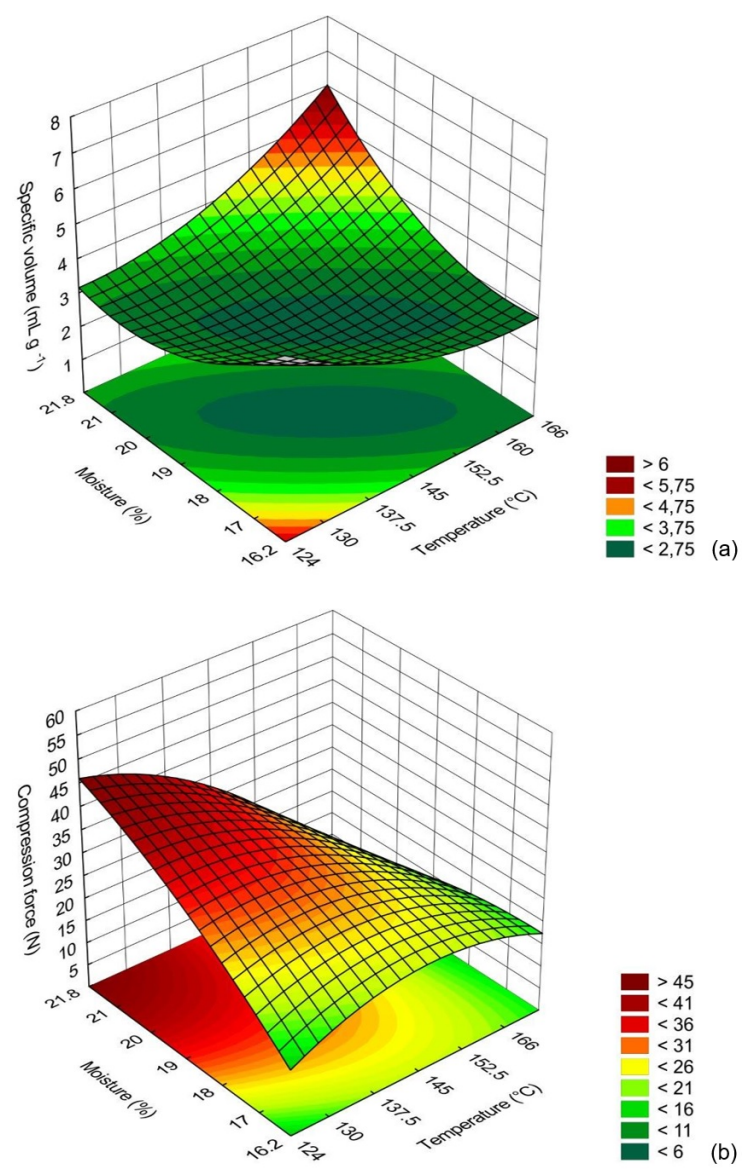

Figure 2. Effect of moisture content and process temperature on the (a) specific volume ( $\left.\mathrm{mL} \mathrm{g}^{-1}\right)$ and (b) compression force $(\mathrm{N})$ of cowpea cotyledons flour extrudates.

$$
S V=2.64+0.26 x_{1}+0.50 x_{1}^{2}-0.01 x_{2}+0.35 x_{2}^{2}+0.66 x_{1} x_{2}
$$

Phillips et al. (1984) obtained extrudates with SV ( $\left.\mathrm{mL} \mathrm{g}^{-1}\right)$ of 2.56 to 4.35, and Berrios et al. (2004) of $2.86 \mathrm{~mL} \mathrm{~g}^{-1}$ using black bean meal ( $V$. unguiculata), values slightly lower than observed in this study. Commercial corn strains exhibit SV between 2.56 to $5.55 \mathrm{~mL} \mathrm{~g}^{-1}$. Higher values are desirable considering that they indicate high crispness in the final product (Maskus \& Arntfield, 2015).

\subsection{Compression force of extrudates}

High moisture contents $(21.8 \%)$ and low temperatures $\left(124^{\circ} \mathrm{C}\right)$ promoted the formation of extrudates with higher $\mathrm{CF}$ values (Figure $2 \mathrm{~b}$ ), as the moisture content decreased and the temperature increased, the extrudates presented lower stiffness, favoring a soft texture to the expanded extrudates.

The value of $\mathrm{CF}$ varied from 15.63 to 47.72 Newton $(\mathrm{N})$ for all the combinations used, the lowest observed value was obtained at $166{ }^{\circ} \mathrm{C}$ and $19 \%$ moisture. The products extruded at $21 \%$ moisture and 130 or $160{ }^{\circ} \mathrm{C}$ did not show significant differences with the lowest $C F$ value (Table 1). The $\mathrm{r}^{2}$ value was 0.83 and the regression model explaining this behavior was significant $(p=0.0254)$. Only the linear coefficient of temperature was significant, presenting the highest absolute value, however, interfering negatively in this characteristic $\left(\beta_{1}=-6.64\right)$, demonstrating how important it was in the characteristic of the resistance of the extrudate to the compressive force. Figure $2 b$ shows a graph with the behavior of the surface according to the obtained model (Equation 4).

$$
C F=30.79-6.64 x_{1}-3.45 x_{1}^{2}+3.50 x_{2}-1.55 x_{2}^{2}-5.40 x_{1} x_{2}
$$


The values obtained for CF were higher than commercial corn extrudates determined by Maskus \& Arntfield (2015) with CF values between 8.86 to 31.24 N. Lira Filho (2002) using WCF obtained values of CF of 10.53 to 58.18 N. Strauta \& Muizniece-Brasava (2016) obtained the lowest CF (28 N) when extruding the whole meal with $9 \%$ of moisture, and the highest value $(43 \mathrm{~N})$ with $13 \%$ of moisture. It will be seen from Figure $2 \mathrm{~b}$ that as the moisture content of the flour is increased and the process temperature is reduced, there is an increase in the CF of the extrudates. This is because the simultaneous changes of the two variables were unfavorable to expansion, resulting in a more compact structure and consequently more rigid, according to Lawton et al. (1985) and Gomez and Aguilera (1984) the expansion is directly related to temperature and inversely to moisture. Extrusion of the CCF with a moisture content of $19 \%$ and temperature $166{ }^{\circ} \mathrm{C}$ resulted in a lower CF value (15.63 N) (Table 1).

\subsection{Water absorption and solubility index}

The values of WAI were influenced by the effects of temperature (linear and quadratic) and moisture (quadratic) (Table 2). CCF conditioned with lower moisture content resulted in extrudates with higher WAI values, except trial 5 extrudates, conditioned with intermediate moisture value (19\%), resulting in the highest WAI value, but did not differ significantly $(p<0.05)$ of treatments 1,2 , and 7 (Table 1) (Figure 3a). The model that best explained this behavior was Equation 5:

$$
W A I=5.50-0.28 x_{1}+0.27 x_{1}^{2}-0.14 x_{2}+0.24 x_{2}^{2}+0.14 x_{1} x_{2}
$$

The value of WAI ranged from 5.34 to $6.54 \mathrm{~g} \mathrm{~g}^{-1}$, the lowest of which were found in the central point region $\left(19 \%\right.$ moisture and $\left.145^{\circ} \mathrm{C}\right)$, all values were well above that of the raw meal $\left(2.86 \mathrm{~g} \mathrm{~g}^{-1}\right)$. Similar values were obtained by Batista et al. (2010) in the raw and extruded whole meal, 2.16 and $5.39 \mathrm{~g} \mathrm{~g}^{-1}$, respectively. Lira Filho (2002) obtained the value of $3.33 \mathrm{~g} \mathrm{~g}^{-1}$ for the raw whole meal and 4.05 to $7.05 \mathrm{~g} \mathrm{~g}^{-1}$ for the extruded ones.

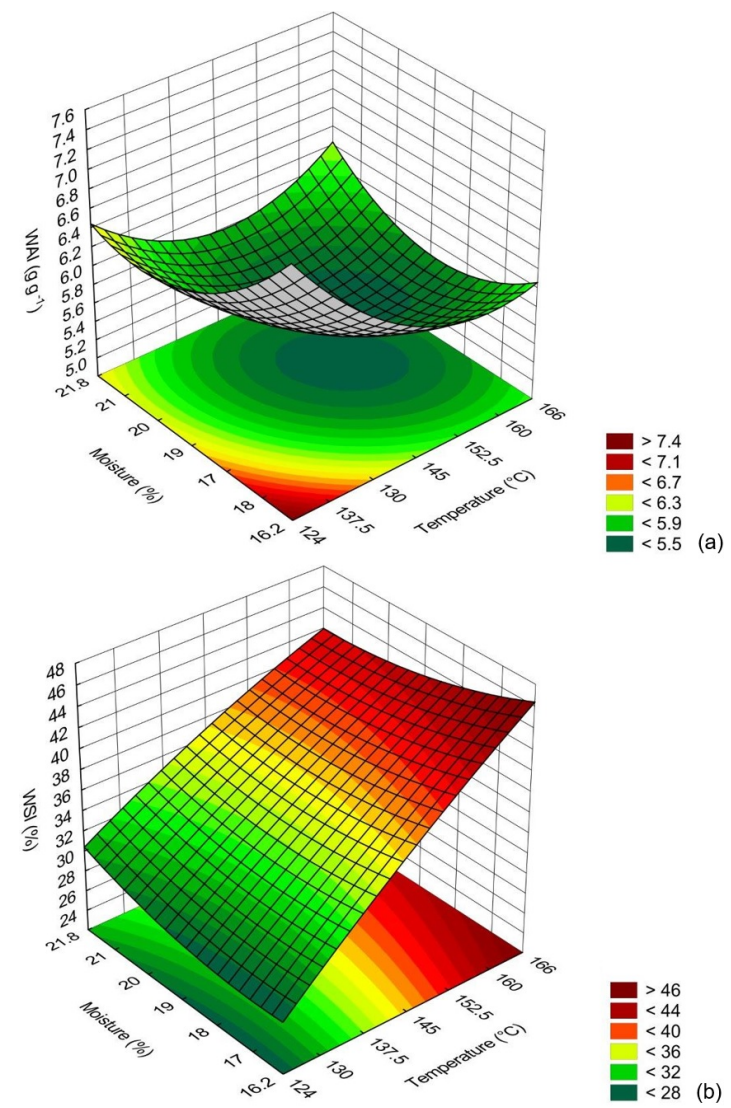

Figure 3. Effect of moisture content and process temperature on the (a) WAI value $\left(\mathrm{g} \mathrm{g}^{-1}\right)$ and (b) WSI (\%) of cowpea cotyledon flour extrudates. 
WSI is often used as an indicator of the degradation of molecular components in extruded food products that solubilize in water (Yang et al., 2008), by measuring the amount of starch degraded or dextrinized during extrusion through a thermomechanical change. WSI values were influenced only by the positive linear effect of temperature (Figure 3b). Regardless of the moisture content used, as the process temperature was elevated, the WSI values increased linearly, the best model that explained this behavior was Equation 6:

$W S I=36.01+5.45 x_{1}-0.36 x_{1}^{2}-0.21 x_{2}+0.58 x_{2}^{2}-0.96 x_{1} x_{2}$

The value of WSI in crude flour was $34.05 \%$, an intermediate value to those obtained in extruded CCF, which ranged from $28.34 \%$ to $43.67 \%$. The highest value obtained was for trial 6 , at the highest temperature $\left(166^{\circ} \mathrm{C}\right)$ and intermediate conditioning moisture $(19 \%)$, differing significantly from the extruded products of the other treatments by the Scott-Knott test $(p \leq 0.05)$, except for the extrudate of trial 3 (Table 1). Similar values were obtained by Batista et al. (2010) in the raw and extruded whole meal, 33.88\% and 34.93\%, respectively. Lira Filho (2002) obtained a low value for the crude whole meal (11.16\%), and from 22.21 to $44.99 \%$ in the extruded flours.

\subsection{Global desirability analysis}

The process conditions that can result in higher values for SV and WAI, and lower CF and WSI or general desirability (D) were determined through simulation in the Statistica program, obtaining a value equal to 1.00 (Figure 4), which is the maximum or desirable value, according to the Lazic scale (2004), and the process condition that provided the best physical and physical-chemical characteristics in the simulation was the combination of $124.2^{\circ} \mathrm{C}$ and $16.3 \%$ of moisture (Figure 4 ).
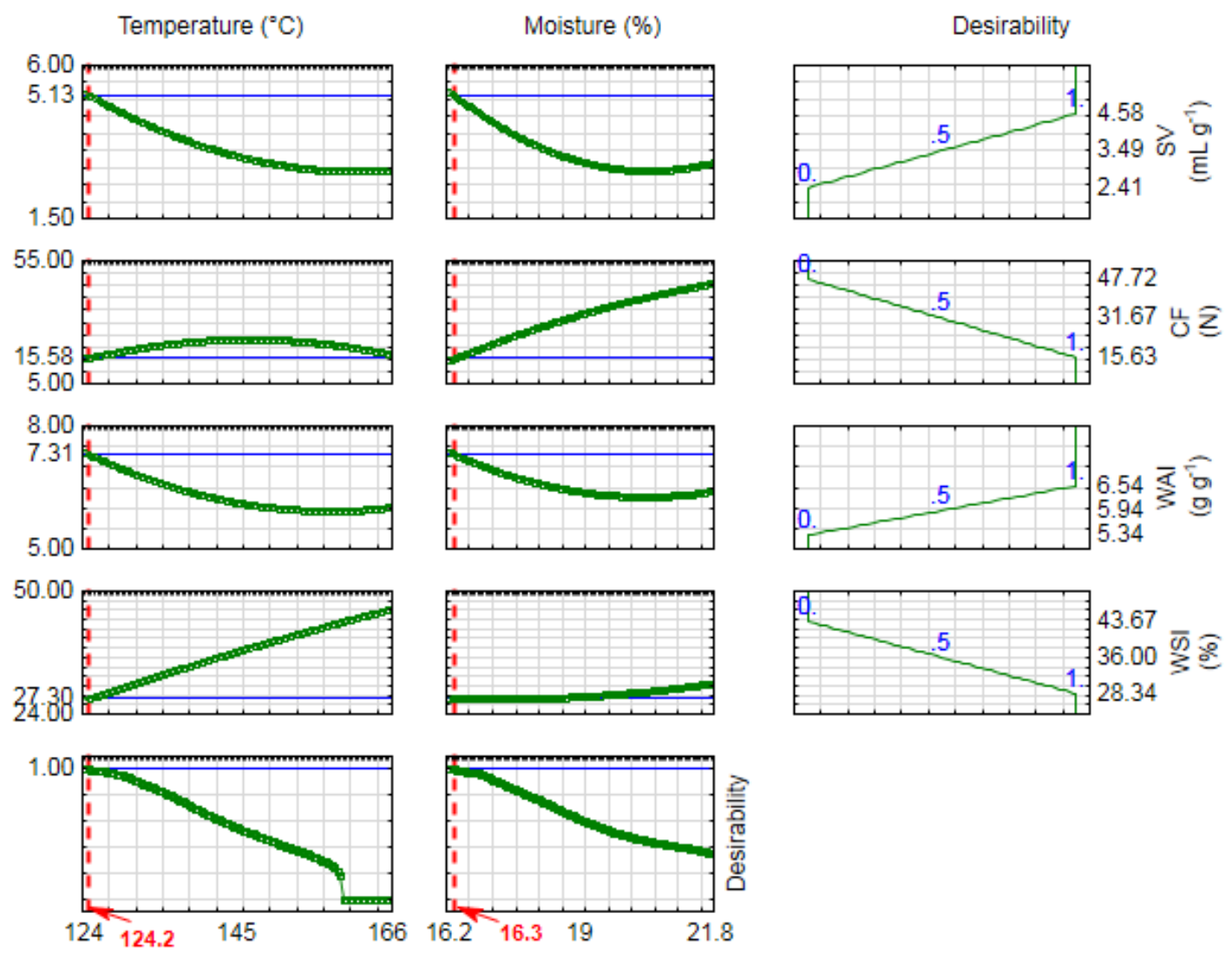

Figure 4. Effect of moisture content and process temperature on profiles for predicted values for dependent variables (SV, CF, WAI, and WSI) and global desirability. 


\section{Conclusions}

The variables, extrusion temperature $\left(\mathrm{x}_{1}\right)$ and Cowpea Cotyledons Flour (CCF) conditioning moisture $\left(\mathrm{x}_{2}\right)$, significantly interfered with the characteristics of specific volume (SV), compression force (CF), water absorption index (WAI), and water solubility index (WSI) of the extrudates. Within the limit studied, the process conditions with the lowest temperature and moisture values resulted in products with the best characteristics, with the highest SV and the lowest CF value. The values of SV showed a behavior like that of WAI, but inverse to CF. The WSI presented a behavior different from the other three response variables. For WAI, the minimum point was observed close to the central point condition and for WSI there is a positive correlation with the extrusion temperature. The maximum global desirability, with higher values for SV and WAI, and lower values for WSI and CF, will be obtained by extruding at a temperature of $124.2{ }^{\circ} \mathrm{C}$ and $16.3 \%$ of moisture. This information is useful for the development of extruded products based on CCF or flour from other legumes. It is necessary to explore the process conditions beyond the limits studied to maximize the value of SV and to minimize the $\mathrm{CF}$.

\section{Acknowledgements}

The authors are grateful to the Brazilian Agricultural Research Corporation (EMBRAPA) for financial support, Process EMBRAPA Management System (SEG) No. 03.14.01.001.00.00.

\section{References}

Aguilera, J. M., Lusas, E. W., Uebersax, M. A., \& Zabik, M. E. (1982). Development of food ingredients from navy beans (Phaseolus vulgaris) by roasting, pin milling, and air classification. Journal of Food Science, 47(4), 1151-1154. http://dx.doi.org/10.1111/j.1365-2621.1982.tb07638.x

Anderson, R. A., Conway, H. F., Pfeifer, V. F., \& Griffin Jr, E. L. (1969). Gelatinization of corn grits by roll and extrusion cooking. Cereal Science Today, 14(1), 4-12.

Anton, A. A., Gary Fulcher, R., \& Arntfield, S. D. (2009). Physical and nutritional impact of fortification of corn starch-based extruded snacks with common bean (Phaseolus vulgaris L.) flour: effect of bean addition and extrusion cooking. Food Chemistry, 113(4), 989-996. http://dx.doi.org/10.1016/j.foodchem.2008.08.050

Association of Official Analytical Chemists - AOAC. (2012). Official methods of analysis of the Association of Official Analytical Chemists (19th ed.). Washington: AOAC.

Barros Neto, B., Scarminio, I. S., \& Bruns, R. E. (2010) Como fazer experimentos: pesquisa e desenvolvimento na ciência e na indústria (4. ed., 414p.). Porto Alegre: Bookman.

Batista, K. A. (2010). Extrusão de farinha de feijão hard-to-cook: características bioquímicas e propriedades funcionais (Master's thesis). Universidade Federal de Goiás, Goiânia.

Batista, K. A., Prudêncio, S. H., \& Fernandes, K. F. (2010). Changes in the biochemical and functional properties of the extruded hard-to-cook (Vigna unguiculata L. Walp.). International Journal of Food Science \& Technology, 45(4), 794-799. http://dx.doi.org/10.1111/j.1365-2621.2010.02200.x

Berrios, J. D. J., Wood, D. F., Whitehand, L., \& Pan, J. (2004). Sodium bicarbonate and the microstructure, expansion and color of extruded black beans. Journal of Food Processing and Preservation, 28(5), 321-355. http://dx.doi.org/10.1111/j.17454549.2004.24008.x

Box, G. E. P., \& Behnken, D. W. (1960). Some new three level designs for the study of quantitative variables. Technometrics, 2(4), 455-475. http://dx.doi.org/10.1080/00401706.1960.10489912

Brasil. Ministério da Agricultura, Pecuária e Abastecimento (2018). Plano Nacional de Desenvolvimento da Cadeia do Feijão e Pulses. Retrieved in 2020, May 04, from http://www.feijaoepulses.agr.br/assets/plano-nacional-feijao-e-pulses-pdf-final.pdf

Carvalho, C. W. P., Takeiti, C. Y., Onwulata, C. I., \& Pordesimo, L. O. (2010). Relative effect of particle size on the physical properties of corn meal extrudates: effect of particle size on the extrusion of corn meal. Journal of Food Engineering, 98(1), 103109. http://dx.doi.org/10.1016/j.jfoodeng.2009.12.015

Deshpande, S. S., Sathe, S. K., Cornforth, D., \& Salunkhe, D. K. (1982). Effects of dehulling on functional properties of dry bean (Phaseolus vulgaris L.) flours. Cereal Chemistry, 59(5), 396-401.

Empresa Brasileira de Pesquisa Agropecuária. (2020). Dados conjunturais da produção de feijão-comum (Phaseolus vulgaris L.) e caupi (Vigna unguiculata (L.) Walp.) no Brasil (1985 a 2018): área, produção e rendimento. (2020). Santo Antônio de Goiás: EMBRAPA. Retrieved in 2020, May 04, from https://www.cnpaf.embrapa.br/socioeconomia/index.htm

Falcone, R. G., \& Phillips, R. D. (1988). Effects of feed composition, feed moisture, and barrel temperature on the physical and rheological properties of snack-like products prepared from cowpea and sorghum flours by extrusion. Journal of Food Science, 53(5), 1464-1469. http://dx.doi.org/10.1111/j.1365-2621.1988.tb09300.x 
Ferreira, C. M., \& Wander, A. E. (2017, December 10). Consumo. Retrieved in 2020, May 04, from http://www.agencia.cnptia.embrapa.br/Repositorio/CONTAG01_62_1311200215103.html

Ferreira, C. M., Del Peloso, M. J., \& Faria, L. C. (2002). Feijão na economia Nacional. Embrapa. Retrieved in 2020, May 04, from https://ainfo.cnptia.embrapa.br/digital/bitstream/CNPAF/19419/1/doc_135.pdf

Ferreira, D. F. (2008). SISVAR: um programa para análises e ensino de estatística. Revista Symposium, 6(2), 36-41.

Food and Agriculture Organization of the United Nations. (2015). International Year of Pulses - Nutritious seeds for a sustainable future. Retrieved from http://www.fao.org/pulses-2016/news/news-detail/en/c/337107/.

Food and Agriculture Organization of the United Nations. (2020, July 10). FAOSTAT. Rome: FAO. Retrieved in 2020, May 04, from http://www.fao.org/faostat/en/\#data/QC/visualize

Gomez, M. H., \& Aguilera, J. M. (1984). A physicochemical model for extrusion of corn starch. Journal of Food Science, 49(1), 40-43. http://dx.doi.org/10.1111/j.1365-2621.1984.tb13664.x

Hashimoto, J. M., \& Grossmann, M. V. E. (2003). Effects of extrusion conditions on quality of cassava bran/cassava starch extrudates. International Journal of Food Science \& Technology, 38(5), 511-517. http://dx.doi.org/10.1046/j.13652621.2003.00700.x

Institute of Medicine of the National Academies. (2005). DRI Report-Energy, Carbohydrate, Fiber, Fat, Fatty Acids, Cholesterol, Protein and Amino Acids (Macronutrients) (1st ed.). Washington: National Academies Press.

Instituto de Tecnologia de Alimentos. (2015). Brasil Food Trends 2020. Retrieved in 2020, May 04, from http://www.brasilfoodtrends.com.br.

Jakkanwar, S. A., Rathod, R. P., \& Annapure, U. S. (2018). Development of cowpea-based (Vigna unguiculata) extruded snacks with improved in vitro protein digestibility. International Food Research Journal, 25(2), 804-813.

Jozinovic, A., Subaric, D., Achar, D., Babic, J., Planinic, M., Pavokovic, M., \& Blazic, M. (2012). Effect of screw configuration, moisture content and particle size of corn grits on properties of extrudates. Croatian Journal of Food Science and Technology, 4(2), 95-101.

Kaur, A., Kaur, S., Singh, M., Singh, N., Shevkani, K., \& Singh, B. (2015). Effect of banana flour, screw speed and temperature on extrusion behavior of corn extrudates. Journal of Food Science and Technology, 52(7), 4276-4285. PMid:26139892. http://dx.doi.org/10.1007/s13197-014-1524-2

Kennedy, M. B., Phillips, R. D., Rao, V. N. M., \& Chinnan, M. S. (1986). Effects of feed moisture and barrel temperature on the rheological properties of extruded cowpea meal. Journal of Food Process Engineering, 8(4), 193-212. http://dx.doi.org/10.1111/j.1745-4530.1986.tb00112.x

Korkerd, S., Wanlapa, S., Puttanlek, C., Uttapap, D., \& Rungsardthong, V. (2016). Expansion and functional properties of extruded snacks enriched with nutrition sources from food processing by-products. Journal of Food Science and Technology, 53(1), 561-570. PMid:26787975. http://dx.doi.org/10.1007/s13197-015-2039-1

Khuri, A. I., \& Cornell, J. A. (1990). Response surface: designs and analysis. New York: Marcel Dekker.

Lawton, J. W., Davis, A. B., \& Behnke, K. C. (1985). High temperature short-time extrusion of wheat gluten and bran-like fraction. Cereal Chemistry, 62(4), 267-269.

Lira Filho, F. J. (2002). Efeitos da extrusão termoplástica sobre as propriedades tecnológicas e nutritivas das proteínas da farinha integral do feijão-caupi (Vigna unguiculata L. Walp.) (Tese de doutorado). Universidade Estadual de Campinas, Campinas.

Marques, M. R. (2013). Ação hipocolesterolêmica de hidrolisados de feijão-caupi (Vigna unguiculata L. Walp.) (Dissertação de mestrado). Universidade de São Paulo, São Paulo.

Maskus, H., \& Arntfield, S. (2015). Extrusion processing and evaluation of an expanded, puffed pea snack product. Journal of Nutrition \& Food Sciences, 5(4), 1-6.

Mesquita, C. B., Leonel, M., \& Mischan, M. M. (2013). Effects of processing on physical properties of extruded snacks with blends of sour cassava starch and flaxseed flour. Food Science and Technology, 33(3), 404-410. http://dx.doi.org/10.1590/S0101-20612013005000073

Omohimi, C. I., Sobukola, O. P., Sarafadeen, K. O., \& Sanni, L. O. (2014). Effect of thermo-extrusion process parameters on selected quality attributes of meat analogue from mucuna bean seed flour. Nigerian Food Journal, 32(1), 21-30. http://dx.doi.org/10.1016/S0189-7241(15)30092-8

Phillips, R. D. (1982). Preparation and composition of a dry milled flour from cowpeas. Journal of the American Oil Chemists' Society, 59(8), 351-353. http://dx.doi.org/10.1007/BF02541018

Phillips, R. D., Chhinnan, M. S., \& Kennedy, M. B. (1984). Effect of feed moisture and barrel temperature on physical properties of extruded cowpea meal. Journal of Food Science, 49(3), 916-921. http://dx.doi.org/10.1111/j.1365-2621.1984.tb13241.x

Rios, M. J. B. L., Damasceno-Silva, K. J., Moreira-Araújo, R. S. R., Figueiredo, E. A. T., Rocha, M. M., \& Hashimoto, J. M. (2018). Chemical, granulometric and technological characteristics of whole flours from commercial cultivars of cowpea. Revista Caatinga, 31(1), 217-224. http://dx.doi.org/10.1590/1983-21252018v31n125rc

Rondini, E. A., Barrett, K. G., \& Bennink, M. R. (2013). Nutrition and human health benefits of dry beans and pulse. In M. Siddiq, \& M. A. Uebersax (Eds.), Dry Beans and Pulses Production, Processing and Nutrition (pp. 335-358). lowa: Wiley-Blackwell.

Schmiele, M. (2009). Caracterização das frações com diferentes granulometrias de milho dentado e duro e avaliação na qualidade de extrusados expandidos (Doctoral dissertation). Retrieved in 2020, May 04, from http://repositorio.unicamp.br/jspui/handle/REPOSIP/255887 
Strauta, L., \& Muizniece-Brasava, S. (2016). The effects of different amounts of additional moisture on the physical properties of cowpea (Vigna unguiculata L. Walp.) extrudates. International Journal of Nutrition and Food Engineering, 10(12), 847-850.

United States Department of Agriculture (2017, December 15). USDA National Nutrient Database for Standard Reference Release 28. Washington: USDA.

Wander, A. E., \& Chaves, M. O. (2011, October 17-20). Consumo per capita de feijão no Brasil de 1998 a $2010:$ uma comparação entre o consumo aparente e consumo domiciliar. In Anais do $10^{\circ}$ Congresso Nacional de Pesquisa de Feijão. Goiânia, Goiás: Embrapa Arroz e Feijão.

Wood, J. A., \& Malcolmson, L. (2011). Milling technologies. In B. Tiwari, A. Gowen, \& B. Mckenna (Eds.), Pulse foods: Processing, quality and nutraceutical application (pp. 193-222). San Diego: Academic Press, Elsevier. http://dx.doi.org/10.1016/B978-0-12-382018-1.00008-3.

Yang, S. H., Peng, J., Lui, W., \& Lin, J. (2008). Effects of adlay species and rice flour ratio on the physicochemical properties and texture characteristic of adlay-based extrudates. Journal of Food Engineering, 84(3), 489-494. http://dx.doi.org/10.1016/j.jfoodeng.2007.06.010

Yuliani, S., Torley, P. J., D’Arcy, B., Nicholson, T., \& Bhandari, B. (2006). Effect of extrusion parameters on flavour retention, functional and physical properties of mixtures of starch and D-limonene encapsulated in milk protein. International Journal of Food Science \& Technology, 41(S2), 83-94. http://dx.doi.org/10.1111/j.1365-2621.2006.01409.x

Funding: Brazilian Agricultural Research Corporation (EMBRAPA). Process EMBRAPA Management System (SEG) 03.14.01.001.00.00 